\title{
Intestinal digestibility of amino acids in rumen undegradable protein estimated using a precision-fed cecectomized rooster bioassay: I. Soybean meal and SoyPlus ${ }^{1}$
}

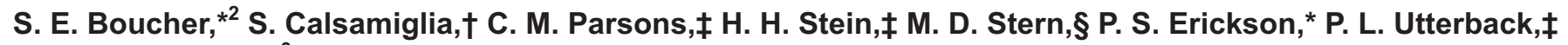 \\ and C. G. Schwab*3 \\ *Department of Biological Sciences, University of New Hampshire, Durham 03824 \\ †Facultad de Veterinaria, Universitat Autònoma de Barcelona, Bellaterra, Spain 08193 \\ ‡Department of Animal Sciences, University of Illinois, Champaign 61801 \\ §Department of Animal Science, University of Minnesota, St. Paul 55108
}

\section{ABSTRACT}

The objectives of this experiment were to measure intestinal digestibility of AA in rumen undegradable protein (RUP-AA) in soybean meal (SBM) and expeller SBM (SoyPlus, West Central, Ralston, IA; SP) and to determine if these feeds contain a constant protein fraction that is undegradable in the rumen and indigestible in the small intestine, as assumed in the French Institut National de la Recherche Agronomique (Paris, France) and Scandinavian AAT-PBV (AAT $=$ AA absorbed from small intestine; $\mathrm{PBV}=$ protein balance in the rumen) models. Three samples of SBM and 3 samples of SP were obtained from the Feed Analysis Consortium Inc. (Savoy, IL). To obtain the RUP fraction, samples were ruminally incubated in situ for $16 \mathrm{~h}$ in 4 lactating cows, and the collected rumen undegraded residues (RUR) were pooled by sample. Subsamples of the intact feeds and RUR were crop intubated to 4 cecectomized roosters, and total excreta were collected for $48 \mathrm{~h}$. Intact feeds, RUR, and excreta were analyzed for AA. Basal endogenous AA loss estimates were obtained from fasted birds and were used to calculate standardized digestibility of AA in the intact feeds and RUP-AA. Indigestibility coefficients of the intact feeds were calculated as $(100-\%$ standardized AA digestibility), and indigestibility of the RUR was calculated as $\{(100-\%$ ruminal degradation of AA $) \times[(100-$ $\%$ standardized RUP-AA digestibility)]/100\}. Results indicated that standardized digestibility of feed-AA was similar to standardized digestibility of RUP-AA for SBM and SP samples and that standardized di-

\footnotetext{
Received November 10, 2008.

Accepted May 28, 2009.

${ }^{1}$ This is Scientific Contribution Number 2391 from the New Hampshire Agricultural Experiment Station (Durham) contributing to regional research project NC-1009.

${ }^{2}$ Present address: William H. Miner Agricultural Research Institute, Chazy, NY 12921.

${ }^{3}$ Corresponding author: charles.schwab@unh.edu
}

gestibility of individual AA differed within samples. Standardized feed-AA and RUP-AA digestibility values were lowest for Lys and Cys and highest for Trp and Met. Results also indicated that SBM and SP did not contain a constant protein fraction that was both undegradable in the rumen and indigestible in the small intestine. Indigestibility values of RUR were lower than in intact feeds, suggesting that SBM and SP contain a protein fraction that is indigestible in the intestine but partly degradable in the rumen, digestible in the intestine after ruminal incubation, or both.

Key words: amino acid digestibility, rumen-undegradable protein, soybean meal

\section{INTRODUCTION}

Some nutritional models recognize that intestinal digestibility of RUP varies among feedstuffs (Vérité and Peyraud, 1989; Madsen et al., 1995; NRC, 2001). However, in these models, digestibility of individual AA in RUP (RUP-AA) is assumed to be the same as digestibility of total RUP. However, digestibility of individual AA in intact feed protein (Batal and Parsons, 2002; Stein et al., 2006) and RUP does vary within a feed (Prestløkken and Rise, 2003). Currently, data reported in the literature on intestinal digestibility of RUP-AA for individual feedstuffs are insufficient to incorporate RUP-AA digestibility coefficients into nutritional models; therefore, research is needed to measure the variation in intestinal digestibility of RUP-AA within and among feeds. Conventional soybean meal (SBM) is one of the most common protein supplements fed to dairy cows, and heat-treated SBM products are often fed to dairy cows to increase the RUP content of the diet. Heat treatment of SBM decreases ruminal microbial degradation of protein, but heat treatment can also potentially decrease RUP and RUP-AA digestibility in the small intestine, particularly Lys (Faldet et al., 1992). Therefore, analysis of RUP-AA digestibility in SBM and heat-treated SBM products is warranted. 
In the Institut National de la Recherche Agronomique (Vérité and Peyraud, 1989) and the Scandinavia AATPBV models (AAT $=$ AA absorbed from small intestine; $\mathbf{P B V}=$ protein balance in the rumen; Madsen et al., 1995), digestibility of RUP is adjusted for changes in ruminal degradability of feed protein. In these models, it is assumed that feedstuffs contain a constant protein fraction that is totally indigestible in the small intestine and also completely undegradable in the rumen. Therefore, true digestibility of RUP is calculated according to the following equation:

$$
\mathrm{TD}=(\mathrm{UDN}-\mathrm{TU}) / \mathrm{UDN},
$$

where TD is the true digestibility of UDN, UDN is ruminally undegraded dietary $\mathrm{N}$, and TU is true indigestible $\mathrm{N}$ in the intact feed. However, Prestløkken and Rise (2003) reported that the assumption that feedstuffs contain a constant undegradable or indigestible protein fraction is not true for all feeds. Further evaluation of this hypothesis is warranted.

The mobile bag technique (MBT) has been the most common method used to estimate intestinal digestibility of RUP and RUP-AA in individual feeds in ruminants (NRC, 2001). However, the MBT is an invasive procedure that requires the animals to be fitted with ruminal, duodenal, and sometimes ileal cannula. This procedure is also very time-consuming, and currently there is no standardized protocol for conducting this procedure. The precision-fed cecectomized rooster assay may be a viable alternative for estimating small intestinal RUP-AA digestibility (Titgemeyer et al., 1990). Titgemeyer et al. (1990) observed a high correlation between estimates of intestinal dietary RUP-AA digestibility made in steers fitted with duodenal and ileal cannulas and estimates from cecectomized roosters in which birds were crop intubated with duodenal digesta collected from the steers.

The objectives of this experiment were 1) to determine digestibility of RUP-AA in SBM and SoyPlus (SP; expeller SBM, West Central, Ralston, IA) using the precision-fed cecectomized rooster assay and 2) to determine if these feedstuffs contained a constant protein fraction that was both undegradable in the rumen and indigestible in the small intestine.

\section{MATERIALS AND METHODS}

\section{Feed Samples}

Two kilograms each of 3 sources of SBM and 3 sources of SP were obtained from the Feed Analysis Consortium Inc. (Champaign, IL). The Feed Analysis Consortium Inc. is a membership-based organization dedicated to the advancement of feed analysis and nu- tritional modeling. Each sample was ground to pass a 2-mm screen using a Wiley mill (Thomas Scientific, Swedesboro, NJ). To assess the effects of excessive heat on intestinal digestibility of RUP and RUP-AA, 1 sample of SBM and 1 sample of SP were heated in a forced hot-air oven (VWR Scientific, West Chester, $\mathrm{PA})$ at $150^{\circ} \mathrm{C}$ for $90 \mathrm{~min}$. This temperature and length of heating were chosen based on the results reported by Faldet et al. (1992), in which growth of rats decreased when they were fed soybeans that were heated at $150^{\circ} \mathrm{C}$ for $90 \mathrm{~min}$.

\section{Ruminal Incubation}

Procedures for the ruminal cannulation surgery and experimental protocol were approved by the Institutional Animal Care and Use Committee at the University of New Hampshire. To provide RUR for use in the precision-fed cecectomized rooster assay and for use in experiments reported previously (Boucher et al., 2009a,b) to evaluate in vitro methods for estimating RUP-AA digestibility, $1.2 \mathrm{~kg}$ of sample (ground to 2 $\mathrm{mm}$ ) was weighed equally into 150 polyester bags so that each bag contained $8 \mathrm{~g}$ of sample. The bags had a mean pore size of $50 \mu \mathrm{m}$ and dimensions of $10 \times 20$ cm (Ankom Technologies, Macedon, NY). Bags were tied with plastic fastening ties $2 \mathrm{~cm}$ below the top of the bag, soaked in $39^{\circ} \mathrm{C}$ water for $15 \mathrm{~min}$, and placed inside 4 mesh laundry bags $(46 \times 56 \mathrm{~cm}$; Whitney Design Inc., St. Louis, MO) for ruminal incubation. The mesh laundry bags were filled with 38 polyester in situ bags of 2 different samples so that 76 bags were in each laundry bag during each incubation. Nine metal washers $($ diameter $=4.3 \mathrm{~cm}$; total weight $=115 \mathrm{~g}$ ) were tied inside each mesh laundry bag, and a $60-\mathrm{cm}$ string was tied to one end of the bag. The mesh laundry bags were inserted into the rumen of 4 ruminally cannulated lactating cows averaging (mean \pm SD) $48 \pm 4$ DIM, and cows were fed a $55 \%$ forage, $45 \%$ concentrate diet. Three separate ruminal incubations with 4 ruminally cannulated cows were required to incubate the 6 samples. One-week intervals were allotted between each incubation.

Samples were ruminally incubated for $16 \mathrm{~h}$. One time point was selected to be representative of total RUP. The 16-h ruminal incubation time was selected for several reasons. First, in a literature search, 16 studies were identified that determined RUP digestibility of SBM using a single time point for ruminal incubation. Of the 16 studies, 11 used a 16 -h ruminal incubation, 1 used a 14-h ruminal incubation, 3 used a 12-h ruminal incubation, and 1 used an 8-h ruminal incubation. To compare estimates obtained in this experiment with those previously reported in the literature, the $16-\mathrm{h} \mathrm{ru}-$ 
minal incubation was selected as the most appropriate. In addition, Calsamiglia and Stern (1995) determined there was no difference in RUP digestibility measured in vitro when concentrate ingredients were ruminally incubated in situ for $12 \mathrm{~h}$ compared with $16 \mathrm{~h}$.

After the 16-h ruminal in situ incubation, bags were removed from the rumen and submerged in cold water within 5 min. Polyester bags were removed from the laundry bags and processed according to the procedure of Gargallo et al. (2006), with some modifications. Bags were rinsed 3 times for $5 \mathrm{~min}$ in an automatic washing machine with a final spin and then suspended in a $0.1 \%$ methylcellulose (M-0262, Sigma, St. Louis, MO) solution and shaken in a water bath (50 rpm; Precision Scientific, Chicago, IL) at $37^{\circ} \mathrm{C}$ for $30 \mathrm{~min}$ to help in the detachment of particle-associated bacteria (Whitehouse et al., 1994). Bags were then rinsed again 3 times for 5 min in an automatic washing machine, followed by a final spin, and then frozen. In the procedure of Gargallo et al. (2006), samples were oven-dried at $55^{\circ} \mathrm{C}$ for $48 \mathrm{~h}$. In the current experiment, samples were lyophilized (Labconco, Kansas City, MO) for $48 \mathrm{~h}$ to ensure that additional heat damage was not imposed on the residual feed. Once lyophilized, residues were composited by sample, weighed, and ground to pass a 1-mm screen for the precision-fed cecectomized rooster assay (Aldrich et al., 1997).

\section{Precision-Fed Cecectomized Rooster Assay}

Procedures for the cecectomy of roosters and the experimental protocol were approved by the Institutional Animal Care and Use Committee at the University of Illinois. The cecectomized rooster digestibility assay used in this experiment was described by Parsons (1985) and Aldrich et al. (1997). Thirty grams of each feed was ground to pass a 1-mm screen and was crop intubated to 4 cecectomized Single Comb White Leghorn roosters. For crop intubation, the beak of the bird was opened and the stem of a funnel was inserted into the crop. Feed was then poured into the funnel and pushed with a plunger (Sibbald, 1983). The ground RUR were also crop intubated to cecectomized roosters, but $30 \mathrm{~g}$ of RUR sample could not be intubated to the roosters because of the bulkiness of the sample. Therefore, the amount of RUR sample intubated was adjusted to the maximum amount that could be comfortably intubated, which was (mean $\pm \mathrm{SD}$ ) $23.7 \pm 1.4$ and $23.6 \pm 1.3 \mathrm{~g}$ for the SP and SBM RUR samples, respectively. The experiments were conducted from June 2006 to January 2008. In each experiment, feed was withheld from the roosters for $24 \mathrm{~h}$ before and $48 \mathrm{~h}$ after intubation of samples, and the birds had access to water at all times.
Roosters were housed individually in wire mesh cages fitted with excreta collection trays, and total excreta were collected for $48 \mathrm{~h}$ and lyophilized (Sibbald, 1983). The same group of birds was used to determine the digestibility of feeds and RUR. Basal endogenous AA excretion was previously determined by 48 -h collection of excreta from fasted birds (Parsons, 1985; NRC, 1994), and the basal endogenous AA loss values were used to calculate standardized feed-AA and RUP-AA digestibility. Standardized digestibility is defined as digestibility estimates calculated by subtracting only basal endogenous AA losses from the outflow of AA (Stein et al., 2007).

\section{Chemical Analysis}

Portions of the RUR, feed, and excreta were ground to pass a $40-\mu \mathrm{m}$ screen (Arthur H. Thomas Co., Philadelphia, PA) for analysis of the complete AA profile via cation-exchange chromatography coupled with postcolumn ninhydrin derivatization and quantification [AOAC, 2000; method 982.30 E(a,b,c); Experimental Station Chemical Laboratories, University of Missouri, Columbia]. For determination of all AA except Met, Cys, and Trp, samples were hydrolyzed with $6 \mathrm{M} \mathrm{HCl}$ before analysis. For determination of Met and Cys content, samples were oxidized with performic acid before acid hydrolysis to convert Met to methionine sulfone and Cys to cysteic acid, and for analysis of Trp content, samples were subjected to alkaline hydrolysis before acid hydrolysis. Intact feeds and RUR were also analyzed for DM, NDF, ADF, neutral detergent-insoluble CP (NDICP), acid detergent-insoluble CP (ADICP), $\mathrm{CP}$, fat, starch, ash, and minerals by using wet chemistry (Dairy One DHI Forage Testing Laboratory, Ithaca, NY). Neutral detergent fiber was analyzed according to the procedure of Van Soest et al. (1991), using the Ankom A200 filter bag technique (Ankom Technology, Fairport, NY). Briefly, samples were digested for 75 min in NDF solution with $4 \mathrm{~mL}$ of $\alpha$-amylase and 20 $\mathrm{g}$ of sodium sulfite added at the beginning of digestion. Samples were then rinsed 2 times in boiling water with $\alpha$-amylase, followed by rinses with boiling water and acetone. Crude protein was analyzed using a combustion analyzer (AOAC, 2000; method 990.03; Leco FP-528, Leco, St. Joseph, MI). For starch analysis, sugar was preextracted from the samples, and starch was determined using a YSI 2700 Select biochemistry analyzer (YSI application note number 319, YSI Incorporated, Yellow Springs, $\mathrm{OH}$ ). Minerals were analyzed using a Thermo Jarrell Ash IRIS Advantage HX Inductively Coupled Plasma Radial Spectrometer (Thermo Jarrell Ash Corporation, Franklin, MA), and fat was 
determined by ether extraction (AOAC, 2000; method 2003.05). Nonfiber carbohydrate was calculated as 100 $-[\mathrm{CP}+(\mathrm{NDF}-\mathrm{NDICP})+$ fat + ash $]$.

\section{Calculations and Statistical Analysis}

Standardized AA digestibility for the intact feeds and standardized RUP-AA digestibility for the RUR were calculated as follows (Stein et al., 2007):

Standardized AA or RUP-AA digestibility, $\%=$ $\{[\mathrm{AA}$ intake - (AA output + basal endogenous AA) $] /$

$$
\text { AA intake }\} \times 100 .
$$

Indigestibility of the intact feed samples was calculated as follows:

Indigestibility $=100-$ standardized digestibility, $\%$.

Indigestibility of AA in the ruminally incubated feeds was calculated according to the equation of Prestløkken and Rise (2003):

$$
\begin{gathered}
\text { Indigestibility }=[(100-16-\mathrm{h} \text { ruminal AA } \\
\text { disappearance }) \times(100-\text { standardized } \\
\text { RUP-AA digestibility })] / 100 .
\end{gathered}
$$

Data were analyzed as a completely randomized design according to the following model:

$$
\mathrm{Y}_{\mathrm{ijkl}}=\mu+\mathrm{F}_{\mathrm{i}}+\mathrm{R}_{\mathrm{ij}}+\mathrm{FR}_{\mathrm{ij}}+\mathrm{P}_{\mathrm{k}}+\mathrm{c}(\mathrm{F})_{\mathrm{ijkl}}+\mathrm{E}_{\mathrm{ijkl}},
$$

where $Y_{i j k l}$ is the dependent variable; $\mu$ is the overall mean; $F_{i}$ is the fixed effect of the ith feed sample $(i=$ $1, \ldots, 6) ; R_{i j}$ is the fixed effect of ruminal incubation of the ith feed sample $(\mathrm{j}=0,1) ; \mathrm{FR}_{\mathrm{ij}}$ is the fixed effect of the interaction between the ith feed sample and the jth ruminal incubation; $P_{k}$ is the random effect of the kth experiment $(\mathrm{k}=1, \ldots, 4) ; \mathrm{c}(\mathrm{F})_{\mathrm{ijk} \mathrm{l}}$ is the random effect of the lth rooster with the ith feed sample, the jth ruminal incubation, and the kth experiment $(1=$ $1, \ldots, 48)$; and $\mathrm{E}_{\mathrm{ijk}}$ is the random residual $[\sim \mathrm{N}(0$, $\left.\left.\sigma^{2}\right)\right]$. The MIXED procedure (SAS Institute, 2002) was used to solve the above model for each feed type. Tukey's Studentized range test was used to compare least squares means among samples. Significance was declared at $P<0.05$ and tendencies are reported at $0.05<P<0.10$. The MEANS procedure of SAS was used to evaluate the difference between digestibility of individual AA and total AA. The absolute value of the difference between digestibility of individual AA and total AA within each rooster was calculated, and these values were used in the MEANS procedure.

\section{RESULTS AND DISCUSSION}

Standardized digestibility estimates obtained for the RUR represent RUP-AA digestibility values, and standardized digestibility estimates obtained for the intact feeds represent feed AA digestibility values. Therefore, throughout the remainder of this manuscript, RUP-AA digestibility refers to digestibility estimates of the RUR and AA digestibility refers to digestibility estimates of the intact feeds.

\section{Chemical Composition and AA Profile of Feeds and RUR}

The chemical composition of the intact feed and RUR of SP and SBM samples is presented in Table 1. The concentrations of $\mathrm{CP}, \mathrm{NDF}, \mathrm{ADF}$, lignin, NDICP, and ADICP increased in the RUR compared with the intact samples, whereas the concentrations of fat, NFC, and ash decreased in the RUR compared with the intact samples. Similar results have been reported in the literature (Frydrych, 1992; Susmel et al., 1994; Vanhatalo and Ketoja, 1995). Frydrych (1992) reported that the N concentration in the 16-h RUR of SBM was greater than in the intact feed, but the author did not report changes in the composition of other components. Vanhatalo and Ketoja (1995) reported that the concentrations of CP, ADF, NDF, and NDF-N were greater in the 12-h RUR of SBM compared with those in the intact feed, and Susmel et al. (1994) reported an increase in CP and crude fiber and a decrease in ash and lipids in the 14-h RUR of SBM. The decrease in the NFC concentration in the RUR of SBM and SP observed in the present experiment was expected because NFC are degraded at a faster rate than $\mathrm{CP}$ and fiber components (Sniffen et al., 1992; NRC, 2001). The CP increase in the RUR compared with the intact feed for SP and SBM may also be partly attributed to microbial contamination of the RUR. Although methylcellulose was used to detach particle-associated bacteria, the procedure does not remove all the bacteria from the undegraded feedstuff (Whitehouse et al., 1994). Heat-treated SP and SBM samples had greater concentrations of NDF, ADF, lignin, NDICP, and ADICP than nonheated samples. This observation was also expected because fiber concentration and CP associated with fiber increase when feeds are heated (Van Soest and Mason, 1991).

Concentrations (\% of total AA) of Lys and Glu decreased slightly and concentrations of Met, Phe, and branched-chain AA (BCAA) increased slightly after the unheated SBM and SP samples were ruminally in- 
Table 1. Chemical composition (\% of DM) and AA profile (\% of total) of SoyPlus and soybean meal samples before (intact feed) and after a 16-h ruminal incubation (rumen residue)

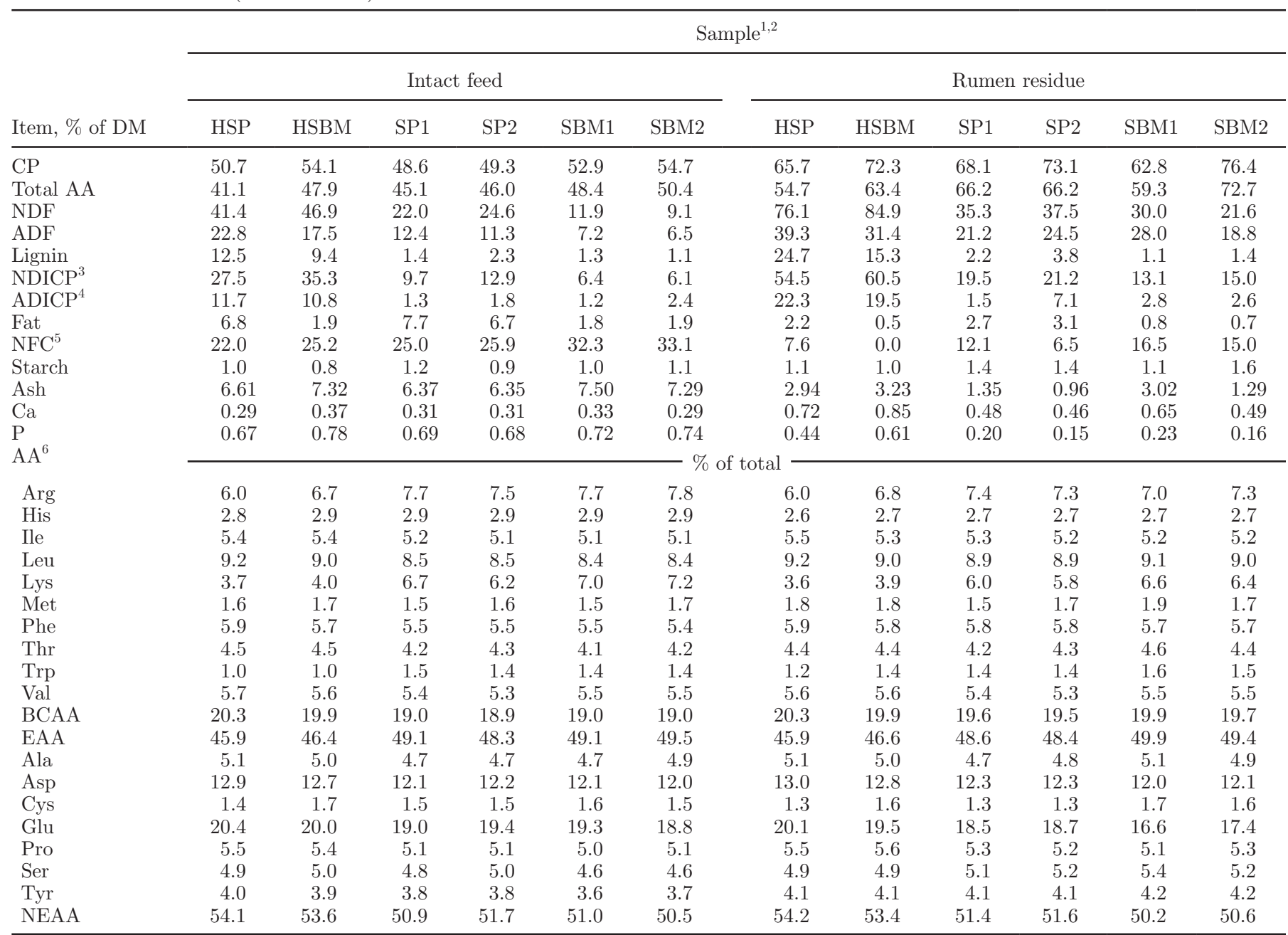

${ }^{1} \mathrm{H}$ indicates the sample was heated at $150^{\circ} \mathrm{C}$ for $90 \mathrm{~min}$; $\mathrm{SP}=$ SoyPlus (West Central, Ralston, IA); SBM = soybean meal.

${ }^{2}$ Numbers following samples indicate these samples are from different sources or batches. Heated samples were independent samples and do not correspond to another sample.

${ }^{3} \mathrm{NDICP}=$ neutral detergent-insoluble CP.

${ }^{4} \mathrm{ADICP}=$ acid detergent-insoluble $\mathrm{CP}$.

${ }^{5} \mathrm{NFC}=100-[\mathrm{CP}+(\mathrm{NDF}-\mathrm{NDICP})+$ fat $+\mathrm{ash}]$.

${ }^{6} \mathrm{BCAA}=$ branched-chain $\mathrm{AA} ; \mathrm{EAA}=$ essential AA; NEAA $=$ nonessential AA.

cubated in situ for $16 \mathrm{~h}$ (Table 1). This indicates that the AA profile of the RUP fraction of SBM and SP differed from the AA profile of the intact feed protein. O'Mara et al. (1997) also observed that the AA profile of SBM protein after ruminal incubation was different from that of the original protein. Soybean meal was ruminally incubated in situ for 8 and $12 \mathrm{~h}$, and Lys and Glu were more degradable and Met, Phe, and the BCAA were more resistant to ruminal degradation compared with the other AA (O'Mara et al., 1997). Cerešnáková et al. (2002) also reported increases in the profile of Phe and the BCAA in the RUR of SBM after samples were ruminally incubated in situ for 16 h. Together, these results support the concept that the AA composition of RUP is different from that of intact feed protein. Two factors can contribute to a difference in the AA profile of the RUR compared with the feed: 1) AA are not degraded at the same rate in the rumen (Prestløkken and Rise, 2003; Borucki-Castro et al., 2007), and 2) microbial contamination of the RUR can result in a different AA profile of feeds after ruminal incubation.

\section{Standardized Digestibility of AA and RUP-AA}

Standardized intestinal AA and RUP-AA digestibility estimates of SP and SBM samples are presented in 
Table 2. Standardized digestibility (\%) of AA in samples of SoyPlus and soybean meal before (intact feed) and after (rumen residue) a 16-h ruminal incubation, determined using the precision-fed cecectomized rooster assay

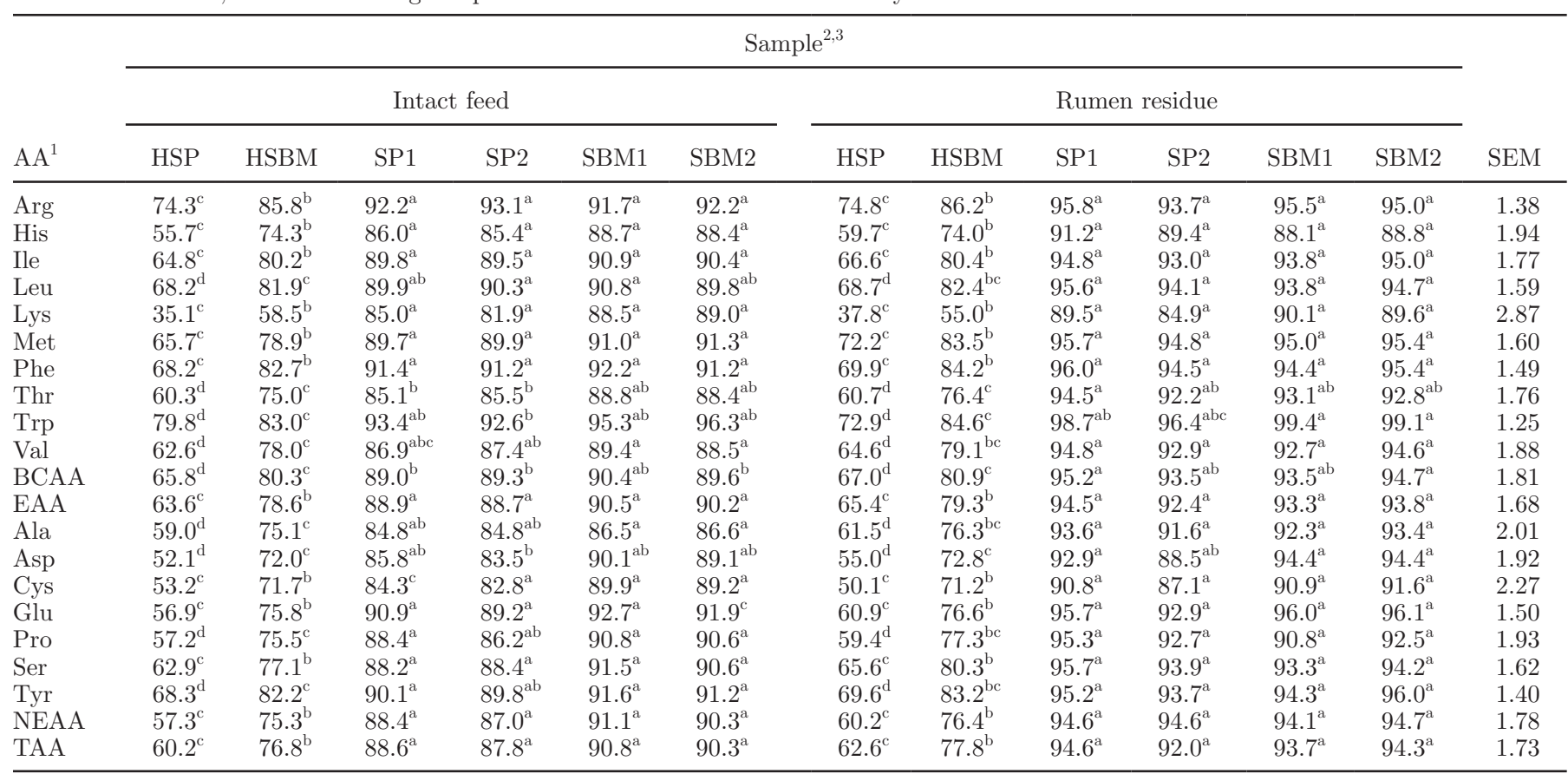

${ }^{\mathrm{a}-\mathrm{d}}$ Least squares means within the same row without a common superscript differ $(P<0.05)$.

${ }^{1} \mathrm{BCAA}=$ branched-chain $\mathrm{AA} ; \mathrm{EAA}=$ essential $\mathrm{AA} ; \mathrm{NEAA}=$ nonessential $\mathrm{AA} ; \mathrm{TAA}=$ total AA.

${ }^{2} \mathrm{H}$ indicates the sample was heated at $150^{\circ} \mathrm{C}$ for $90 \mathrm{~min}$; $\mathrm{SP}=$ SoyPlus (West Central, Ralston, IA); $\mathrm{SBM}=$ soybean meal.

${ }^{3}$ Numbers following samples indicate these samples are from different sources or batches. Heated samples were independent samples and do not correspond to another sample.

Table 2. Heating the SBM and SP samples at $150^{\circ} \mathrm{C}$ for 90 min depressed digestibility of total AA compared with the unheated samples. This effect was likely due to protein cross-linking reactions that occur in the more advanced stages of the Maillard reaction, which can depress digestibility of total protein (Mauron, 1990). Heating the SBM and SP samples particularly depressed Lys digestibility. This was expected because the Maillard reaction decreases Lys digestibility and bioavailability (Mauron, 1990; Faldet et al., 1992). To determine the bioavailability of Lys in roasted soybeans, Faldet et al. (1992) fed rats soybeans roasted at various temperatures for various periods in combination with a basal diet in which Lys was limiting for growth. Growth of rats fed the experimental diets was compared with growth of rats fed a Lys-adequate diet. Soybeans that were roasted at $150^{\circ} \mathrm{C}$ for $90 \mathrm{~min}$ (same heat treatment as used in the present study) caused a depression in rat growth compared with rats fed soybeans that were heated at lower temperatures, for shorter periods, or both.

Standardized AA and RUP-AA digestibility was similar between SP and SBM samples (Table 2), and standardized AA digestibility estimates of these samples agree with reference standardized AA digestibility estimates of SBM for poultry (NRC, 1994). Estimates of RUP-total AA digestibility of the SBM and SP samples obtained in the current experiment ranged from 92 to $95 \%$, which is consistent with the NRC (2001) RUP digestibility value of $93 \%$ for SBM (NRC, 2001).

Digestibility of RUP-AA in SBM has been measured in several experiments (Griffin et al., 1993; Masoero et al., 1994; O'Mara et al., 1997; Van Straalen et al., 1997; Cerešnáková et al., 2002; Prestløkken and Rise, 2003; Taghizadeh et al., 2005; Borucki-Castro et al., 2007). From these studies, 11 RUP-AA digestibility estimates of SBM were obtained. The MBT with collection of bags from the feces was used for 9 estimates (Masoero et al., 1994; O'Mara et al., 1997; Van Straalen et al., 1997; Cerešnáková et al., 2002; Prestløkken and Rise, 2003; Taghizadeh et al., 2005; Borucki-Castro et al., 2007), the MBT with collection of bags from the ileum was used for 2 estimates (Prestløkken and Rise, 2003), and the precision-fed rooster assay was used for 1 estimate (Griffin et al., 1993). Average estimates for RUP-total AA, RUP-total essential AA, RUP-Lys, and RUP-Met 
digestibility reported in these studies were (mean \pm SD) $96 \pm 5,96 \pm 5,96 \pm 4$, and $97 \pm 3 \%$, respectively. In the present study, average estimates for RUP-total AA, RUP-total essential AA, RUP-Lys, and RUP-Met in the SP and SBM samples were (mean \pm SD) $94 \pm$ $1,94 \pm 1,89 \pm 2$, and $95 \pm 1 \%$, respectively. Average RUP-AA digestibility estimates reported in the current experiment generally fell within reported ranges. However, for RUP-Lys, the digestibility estimate of $89 \%$ observed in the present experiment was lower than the average value of $96 \%$. This discrepancy may be due to differences among samples, but may also be attributed to differences in the techniques used. With the MBT, collection of bags from the ileum is preferred to collection of bags from the feces because microbial fermentation in the large intestine can influence digestibility estimates. Another concern with the MBT is that AA that disappear from the bag are assumed to be absorbed in the small intestine. However, this assumption does not account for nutrient antagonism and competition for AA transport systems in the small intestine.

Standardized AA digestibility was similar to standardized RUP-AA digestibility, which is in agreement with several observations reported in the literature (de Boer et al., 1987; Vanhatalo et al., 1995; Beckers et al., 1996). However, some authors have reported differences in $\mathrm{CP}$ and AA digestibility between intact and ruminally incubated SBM (Vanhatalo and Ketoja, 1995; Prestløkken and Rise, 2003). Vanhatalo and Ketoja (1995) reported that CP digestibility of intact SBM (88.9\%) was higher than RUP digestibility (82.5\%). Prestløkken and Rise (2003) also reported that 16-h ruminal incubation of feeds increased CP and AA digestibility, with digestibility of CP in intact SBM equal to $96.7 \%$ and RUP digestibility equal to $99.2 \%$. Although these authors reported differences in $\mathrm{CP}$ and AA digestibility between intact and ruminally incubated SBM, the reported differences were small. Therefore, based on results reported in this experiment and those reported by others (de Boer et al., 1987; Vanhatalo et al., 1995; Beckers et al., 1996), it was concluded that intestinal AA digestibility could be determined using intact SBM and SP. However, to predict the metabolizable AA supply accurately, SBM and SP would need to be ruminally incubated to determine changes in AA profile after ruminal incubation because differential rates of AA degradation may result in a different AA profile for RUP compared with the original feedstuff.

\section{Indigestibility of Intact and Ruminally Incubated Feeds}

Indigestibility coefficients of intact feed and ruminally incubated samples of SP and SBM are presented in
Table 3. For unheated SP and SBM samples, indigestibility of AA in ruminally incubated samples was lower compared with intact feeds, suggesting that SP and SBM do not contain a constant protein fraction that is neither degradable in the rumen nor digestible in the small intestine, as assumed in the Institut National de la Recherche Agronomique and AAT-PBV systems.

Hvelplund et al. (1992), Volden and Harstad (1995), and Prestløkken and Rise (2003) also evaluated the indigestibility of intact and ruminally incubated SBM. Hvelplund et al. (1992) and Prestløkken and Rise (2003) used the MBT with collection of bags from the ileum, and Volden and Harstad (1995) used the MBT with collection of bags from the feces in dairy cows to obtain these estimates. Hvelplund et al. (1992) and Volden and Harstad (1995) measured indigestibility of total CP, whereas Prestløkken and Rise (2003) measured indigestibility of total and individual AA. Hvelplund et al. (1992) reported that increased degradability of protein in the rumen decreased intestinal digestibility of SBM protein, and that intestinal digestibility of the 96-h RUR of SBM was similar to intestinal digestibility of the intact feed. This observation led the authors to conclude that the indigestible $\mathrm{CP}$ fraction of the intact protein was also undegradable in the rumen. Volden and Harstad (1995) reported that CP indigestibility of intact SBM was not different from indigestibility of SBM ruminally incubated in situ for $16 \mathrm{~h}$, and indigestibility coefficients of intact and ruminally incubated SBM were 2.2 and $2.4 \%$, respectively. In contrast, in the present experiment, total AA indigestibility of SBM and SP was higher than total AA indigestibility of ruminally incubated samples. Indigestibility of total AA in intact SP and SBM samples ranged from 9.2 to $12.2 \%$, and indigestibility of total AA in ruminally incubated samples ranged from 0.1 to $2.2 \%$. Decreased indigestibility of the ruminally incubated samples resulted because intestinal RUP-AA digestibility was higher than intestinal AA digestibility. Increased intestinal digestibility of RUP-AA compared with digestibility of AA in the intact feed may be attributed to increased availability of fiber-bound protein after ruminal incubation (Prestløkken and Rise, 2003).

Prestløkken and Rise (2003) also observed that total AA indigestibility of intact SBM and SoyPass was higher than total AA indigestibility of ruminally incubated SBM and SoyPass. Indigestibility estimates for the intact SBM and SoyPass were 3.3 and 3.5\%, respectively, and indigestibility estimates of ruminally incubated SBM and SoyPass were 0.7 and 1.6\%, respectively. Indigestibility coefficients of intact SBM and SP samples in the present study were higher than those observed by Volden and Harstad (1995) and Prestløkken and Rise (2003), but indigestibility estimates of 
Table 3. Indigestibility (\%) of AA in intact and ruminally incubated samples of SoyPlus and soybean meal

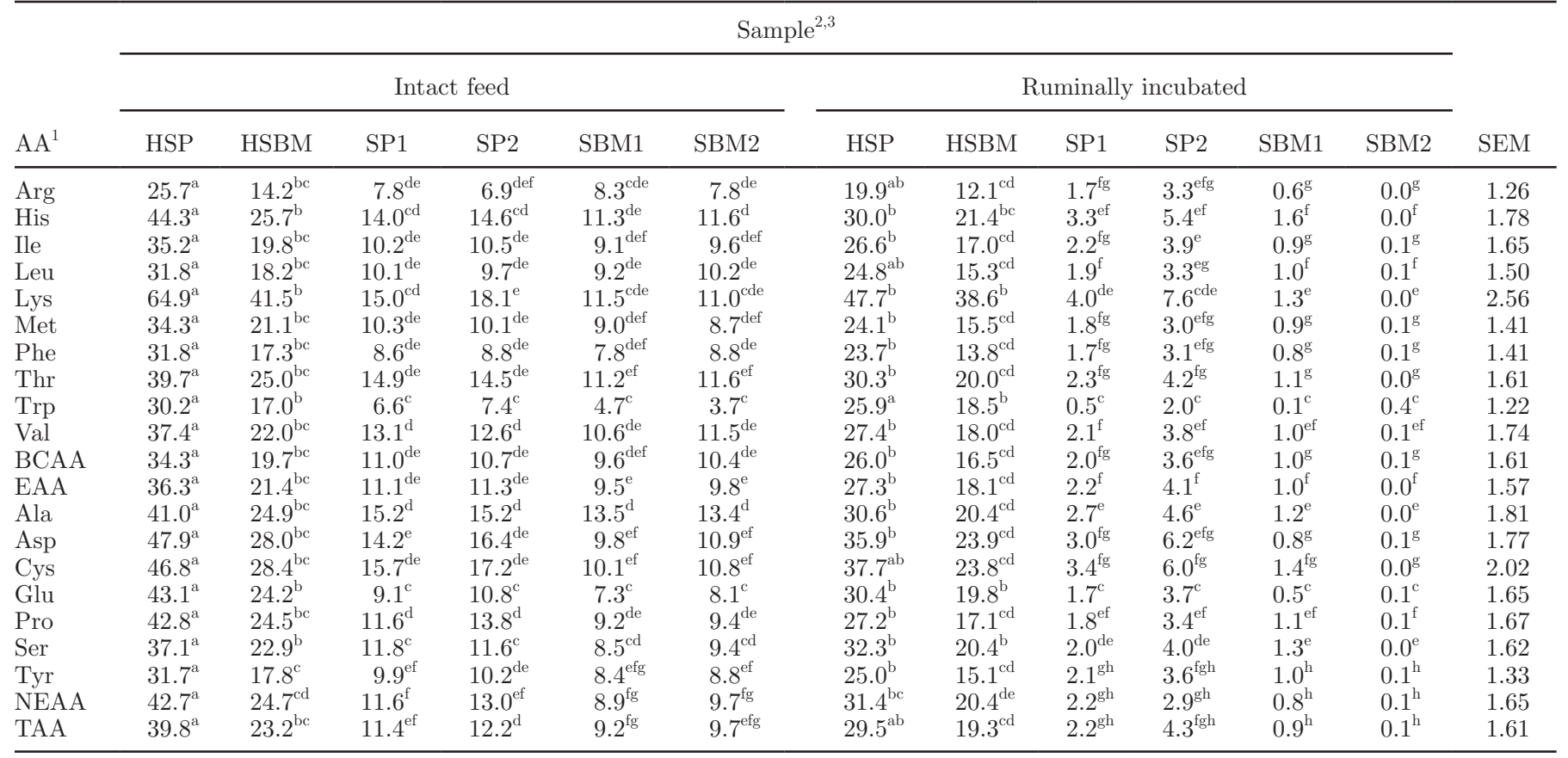

${ }^{\mathrm{a}-\mathrm{h}}$ Least squares means within the same row without a common superscript differ $(P<0.05)$.

${ }^{1} \mathrm{BCAA}=$ branched-chain $\mathrm{AA} ; \mathrm{EAA}=$ essential $\mathrm{AA} ; \mathrm{NEAA}=$ nonessential $\mathrm{AA} ; \mathrm{TAA}=$ total $\mathrm{AA}$

${ }^{2} \mathrm{H}$ indicates the sample was heated at $150^{\circ} \mathrm{C}$ for $90 \mathrm{~min}$; $\mathrm{SP}=$ SoyPlus (West Central, Ralston, IA); SBM = soybean meal.

${ }^{3}$ Numbers following samples indicate these samples are from different sources or batches. Heated samples were independent samples and do not correspond to another sample.

ruminally incubated SBM and SP samples were similar among studies. Although indigestibility estimates of intact SP and SBM samples were higher than the values these authors reported, digestibility estimates of SBM concurred with NRC (1994) reference AA digestibility values. The difference in indigestibility estimates may also be attributed to the different techniques used to determine intestinal AA digestibility (i.e., the MBT vs. the precision-fed rooster assay).

Because indigestibility values were lower for ruminally incubated samples compared with intact feeds, as reported by Prestløkken and Rise (2003) and in the present experiment, SBM and SP appeared to contain a protein fraction that was indigestible in the small intestine but partly degraded in the rumen, digested in the small intestine after ruminal incubation, or both. Because few studies to date have tested this hypothesis, and to our knowledge, no other studies have used the precision-fed rooster assay, more research is needed to clarify reported discrepancies regarding indigestibility estimates of SBM.

\section{Digestibility of Individual AA Versus Total AA}

In NRC (2001), RUP digestibility coefficients are assigned to individual feedstuffs, which is an improve- ment compared with NRC (1989), which assumed 80\% RUP digestibility for all feeds. However, both the swine (NRC, 1998) and poultry (NRC, 1994) NRC models assign intestinal digestibility coefficients to individual AA within feeds. Therefore, in the advancement of ruminant nutrition models, it may be beneficial to assign intestinal digestibility coefficients to individual RUPAA within feeds.

To evaluate the difference between digestibility of individual $\mathrm{AA}$ and total $\mathrm{AA}$, the absolute value of the difference between digestibility of individual AA and total AA in intact and ruminally incubated SP and SBM samples was calculated (Table 4). The absolute value of the difference between digestibility of individual $\mathrm{AA}$ and total $\mathrm{AA}$ was greater than zero for all AA. The mean difference for the ruminally incubated samples ranged from (mean \pm SD) $1.02 \pm 0.9$ for Val to $11.4 \pm 9.5$ for Lys. When the heat-treated samples were removed from the analysis, the difference between Lys digestibility and total AA digestibility within the ruminally incubated SP and SBM samples was smaller $(5.14 \pm 1.7$; data not shown), but it was still different from zero. Because the absolute value of the difference between digestibility of individual RUP-AA and total RUP-AA in SP and SBM samples was greater than zero 
Table 4. Absolute value of the mean difference between standardized digestibility of individual AA and total $\mathrm{AA}$ in intact and ruminally incubated samples (mean $\pm \mathrm{SD})$ of SoyPlus and soybean meal ${ }^{1}$

\begin{tabular}{lcccc}
\hline $\mathrm{AA}^{2}$ & Intact feed & $P$-value & Ruminally incubated & $P$-value \\
\hline Arg & $5.83 \pm 4.67$ & $<0.001$ & $4.40 \pm 4.59$ & $<0.001$ \\
His & $2.67 \pm 1.87$ & $<0.001$ & $3.97 \pm 1.57$ & $<0.001$ \\
Ile & $1.91 \pm 1.69$ & $<0.001$ & $1.53 \pm 1.44$ & $<0.001$ \\
Leu & $2.92 \pm 2.90$ & $<0.001$ & $2.42 \pm 2.38$ & $<0.001$ \\
Lys & $9.41 \pm 9.38$ & $<0.001$ & $11.35 \pm 9.53$ & $<0.001$ \\
Met & $2.08 \pm 1.81$ & $<0.001$ & $3.63 \pm 3.28$ & $<0.001$ \\
Phe & $3.73 \pm 2.63$ & $<0.001$ & $3.24 \pm 2.84$ & $<0.001$ \\
Thr & $1.98 \pm 1.17$ & $<0.001$ & $1.09 \pm 0.71$ & $<0.001$ \\
Trp & $5.99 \pm 2.71$ & $<0.001$ & $6.04 \pm 2.87$ & $<0.001$ \\
Val & $1.50 \pm 0.86$ & $<0.001$ & $1.02 \pm 0.86$ & $<0.001$ \\
BCAA & $2.02 \pm 1.98$ & $<0.001$ & $0.94 \pm 1.64$ & $<0.001$ \\
EAA & $1.15 \pm 1.22$ & $<0.001$ & $1.22 \pm 1.25$ & \\
NEAA & $1.00 \pm 1.02$ & & & \\
\hline
\end{tabular}

${ }^{1}$ Three samples of SoyPlus (West Central, Ralston, IA) and 3 samples of soybean meal each were fed to 4 birds; $\mathrm{n}=24$.

${ }^{2} \mathrm{BCAA}=$ branched-chain $\mathrm{AA} ; \mathrm{EAA}=$ essential AA; NEAA $=$ nonessential AA.

${ }^{3}$ Probability that the absolute value of the difference is greater than zero.

for all AA, if digestibility coefficients are assigned to individual RUP-AA within these feedstuffs, predictions of the metabolizable AA supply may be improved.

\section{CONCLUSIONS}

Standardized digestibility of AA was similar to digestibility of RUP-AA for SBM and SP samples. Digestibility of RUP-Lys was generally lower than digestibility of RUP-total AA. If individual digestibility values were assigned to all AA in RUP, including Lys, better predictions of metabolizable AA supply could be achieved. Soybean meal and SP samples do not contain a constant protein fraction that is neither degradable in the rumen nor digestible in the small intestine. These feeds contain a protein fraction that is indigestible in the small intestine, but partly degraded in the rumen, digested in the small intestine after ruminal incubation, or both. Future analysis should focus on estimating digestibility of individual AA rather than digestibility of total RUP to improve predictions of the metabolizable AA supply in ruminant nutrition models.

\section{ACKNOWLEDGMENTS}

The authors thank West Central (Ralston, IA), Adisseo (Antony, France), Novus International Inc. (St. Louis, MO), and Venture Milling (Salisbury, MD) for financial support of this project. We also thank the staff at the Fairchild Dairy Teaching and Research Center (University of New Hampshire, Durham) for feeding and caring for the cows and the following individuals who helped with this experiment: Anna Pape, Holli Pinard, Heather Tucker, Nancy Whitehouse, and Carly Crawford (University of New Hampshire, Durham, $\mathrm{NH})$.

\section{REFERENCES}

Aldrich, C. G., N. R. Merchen, C. M. Parsons, H. S. Hussein, S. Ingram, and J. R. Clodfelter. 1997. Assessment of postruminal amino acid digestibility of roasted and extruded whole soybeans with the precision-fed rooster assay. J. Anim. Sci. 75:3046-3051.

AOAC. 2000. Official Methods of Analysis. 17th ed. Vol. 1 and 2. AOAC Int., Gaithersburg, MD.

Batal, A. B., and C. M. Parsons. 2002. Effects of age on nutrient digestibility in chicks fed different diets. Poult. Sci. 81:400-407.

Beckers, Y., A. Théwis, and B. Maudoux. 1996. Intestinal digestibility of rumen undegraded $\mathrm{N}$ of concentrates measured by the mobile nylon bag technique. Anim. Feed Sci. Technol. 61:305-323.

Borucki-Castro, S. I., L. E. Phillip, H. Lapierre, P. W. Jardon, and R. Berthiaume. 2007. Ruminal degradability and intestinal digestibility of protein and amino acids in treated soybean meal product. J. Dairy Sci. 90:810-812.

Boucher, S. E., S. Calsamiglia, C. M. Parsons, M. D. Stern, M. Ruiz Moreno, M. Vázquez-Añón, and C. G. Schwab. 2009a. In vitro digestibility of individual amino acids in rumen-undegraded protein: The modified three-step procedure and the immobilized digestive enzyme assay. J. Dairy Sci. 92:3939-3950.

Boucher, S. E., C. Pedersen, H. H. Stein, and C. G. Schwab. 2009b. Evaluation of the furosine and homoarginine methods for determining reactive lysine in rumen-undegraded protein. J. Dairy Sci. 92:3951-3958.

Calsamiglia, S., and M. D. Stern. 1995. A three-step in vitro procedure for estimating intestinal digestion of protein in ruminants. J. Anim. Sci. 73:1459-1465.

Cerešnáková, Z., A. Sommer, M. Chrenková, and P. Dolešová. 2002. Amino acid profile of escaped feed protein after rumen incubation and their intestinal digestibility. Arch. Anim. Nutr. 56:409-418.

de Boer, G., J. J. Murphy, and J. J. Kennelly. 1987. Mobile nylon bag for estimating intestinal availability of rumen undegradable protein. J. Dairy Sci. 70:977-982.

Faldet, M. A., L. D. Satter, and G. A. Broderick. 1992. Determining optimal heat treatment of soybeans by measuring available lysine chemically and biologically with rats to maximize protein utilization by ruminants. J. Nutr. 122:151-160.

Frydrych, Z. 1992. Intestinal digestibility of rumen undegraded protein of various feeds as estimated by the mobile bag technique. Anim. Feed Sci. Technol. 37:161-172.

Gargallo, S., S. Calsamiglia, and A. Ferret. 2006. Technical note: A modified three-step in vitro procedure to determine intestinal digestion of proteins. J. Anim. Sci. 84:2163-2167.

Griffin, C. D. Jr., L. D. Bunting, L. S. Sticker, and B. Vora. 1993. Assessment of protein quality in heat-treated soybean products 
using the growth responses of lambs and calves and a nylon-bag rooster assay. J. Anim. Sci. 71:1924-1931.

Hvelplund, T., M. R. Weisbjerg, and L. S. Andersen. 1992. Estimation of the true digestibility of rumen undegraded dietary protein in the small intestine of ruminants by the mobile bag technique. Acta Agric. Scand. Sect. Anim. Sci. 42:34-39.

Madsen, J., T. Hvelplund, M. R. Weisbjerg, J. Bertilsson, I. Olsson, R. Spörndly, O. M. Harstad, H. Volden, M. Tuori, T. Varvikko, P. Huhtanen, and B. L. Olafsson. 1995. The AAT/PBV protein evaluation system for ruminants. A revision. Nor. J. Agric. Sci. Suppl. 19:3-37.

Masoero, F., L. Fiorentini, F. Rossi, and A. Piva. 1994. Determination of nitrogen intestinal digestibility in ruminants. Anim. Feed Sci. Technol. 48:253-263

Mauron, J. 1990. Influence of processing on protein quality. J. Nutr. Sci. Vitaminol. (Tokyo) 36:S57-S69.

NRC. 1989. Nutrient Requirements of Dairy Cattle. 6th rev. ed. Natl. Acad. Sci., Washington, DC.

NRC. 1994. Nutrient Requirements of Poultry. 9th rev. ed. Natl. Acad. Sci. Washington, DC.

NRC. 1998. Nutrient Requirements of Swine. 10th rev. ed. Natl. Acad. Sci., Washington, DC.

NRC. 2001. Nutrient Requirements of Dairy Cattle. 7th rev. ed. Natl. Acad. Sci., Washington, DC.

O'Mara, F. P., J. J. Murphy, and M. Rath. 1997. The amino acid composition of protein feedstuffs before and after ruminal incubation and after subsequent passage through the intestines of dairy cows. J. Anim. Sci. 75:1941-1949.

Parsons, C. M. 1985. Short note: Influence of caecectomy on digestibility of amino acids by roosters fed distillers' dried grains with solubles. J. Agric. Sci. 104:469-472.

Prestløkken, E., and O. Rise. 2003. Protein and amino acid digestibility in dairy cows measured with mobile nylon bags recovered in ileum or in faeces. Acta Agric. Scand., Sect. Anim. Sci. 53:11-20.

SAS Institute. 2002. SAS/STAT User's Guide. Version 9.1 Edition. SAS Inst. Inc., Cary, NC.

Sibbald, I. R. 1983. Pages 1-89 in The TME System of Feed Evaluation. Agriculture Canada.

Sniffen, C. J., J. D. O'Connor, P. J. Van Soest, D. G. Fox, and J. B. Russell. 1992. A net carbohydrate and protein system for evaluating diets: II. Carbohydrate and protein availability. J. Anim. Sci. 70:3562-3577.

Stein, H. H., M. L. Gibson, C. Pedersen, and M. G. Boersma. 2006. Amino acid and energy digestibility in ten samples of distillers dried grain with solubles fed to growing pigs. J. Anim. Sci. 84:853-860.
Stein, H. H., B. Sève, M. F. Fuller, P. J. Moughan, and C. F. M. de Lange. 2007. Invited review: Amino acid bioavailability and digestibility in pig feed ingredients: Terminology and application. J. Anim. Sci. 85:172-180.

Susmel, P., M. Antongiovanni, B. Stefanon, C. R. Mills, V. A. Hindle, and A. M. van Vurren. 1994. Biological and chemical assessment of feed proteins before and after rumen exposure. Anim. Feed Sci. Technol. 49:119-132.

Taghizadeh, A., M. Danesh Mesgaran, R. Valizadeh, F. Eftekhar Shahroodi, and K. Stanford. 2005. Digestion of feed amino acids in the rumen and intestine of steers measured using a mobile nylon bag technique. J. Dairy Sci. 88:1807-1814.

Titgemeyer, E., N. Merchen, Y. Han, C. Parsons, and D. Baker. 1990. Assessment of intestinal amino acid availability in cattle by use of the precision-fed cecectomized rooster assay. J. Dairy Sci. 73:690-693.

Van Soest, P. J., and V. C. Mason. 1991. The influence of the Maillard reaction upon the nutritive value of fibrous feeds. Anim. Feed Sci. Technol. 32:45-53.

Van Soest, P. J., J. B. Robertson, and B. A. Lewis, 1991. Methods for dietary fiber, neutral detergent fiber, and nonstarch polysaccharides in relation to animal nutrition. J. Dairy Sci. 74:3583-3597.

Van Straalen, W. M., J. J. Odinga, and W. Mostert. 1997. Digestion of feed amino acids in the rumen and small intestine of dairy cows measured with nylon-bag techniques. Br. J. Nutr. 77:83-97.

Vanhatalo, A., I. Aronen, and T. Varvikko. 1995. Intestinal nitrogen digestibility of heat-moisture treated rapeseed meals as assessed by the mobile-bag method in cows. Anim. Feed Sci. Technol. $55: 139-152$.

Vanhatalo, A., and E. Ketoja. 1995. The role of the large intestine in post-ruminal digestion of feeds as measured by the mobile-bag method in cattle. Br. J. Nutr. 73:491-505.

Vérité, R., and J. L. Peyraud. 1989. Protein: The PDI systems. Pages 33-48 in Ruminant Nutrition: Recommended Allowances and Feed Tables. R. Jarrige, ed. John Libbey and Co. Ltd., London, UK.

Volden, H., and O. M. Harstad. 1995. Effect of rumen incubation on the true indigestibility of feed protein in the digestive tract determined by nylon bag techniques. Acta Agric. Scand., Sect. Anim. Sci. 45:106-115.

Whitehouse, N. L., V. M. Olson, C. G. Schwab, W. R. Chesbro, K. D. Cunningham, and T. Lykos. 1994. Improved techniques for dissociating particle-associated mixed ruminal microorganisms from ruminal digesta solids. J. Anim. Sci. 72:1335-1343. 